\title{
Microbacterium ulmi sp. nov., a xylanolytic, phosphate-solubilizing bacterium isolated from sawdust of Ulmus nigra
}

\author{
Raúl Rivas, Martha E. Trujillo, Manuel Sánchez, Pedro F. Mateos, \\ Eustoquio Martínez-Molina and Encarna Velázquez \\ Departamento de Microbiología y Genética, Edificio Departamental, Campus Miguel de \\ Unamuno, Universidad de Salamanca, 37007 Salamanca, Spain
}

Correspondence Martha E. Trujillo mett@usal.es

\begin{abstract}
A xylanolytic and phosphate-solubilizing bacterium isolated from sawdust of Ulmus nigra in Salamanca was characterized by a polyphasic approach. The novel strain, designated XIL02 ${ }^{\top}$, was Gram-positive, aerobic, catalase- and oxidase-negative, rod-shaped and non-motile. Phylogenetically and chemotaxonomically, it was related to members of the genus Microbacterium. According to $16 \mathrm{~S}$ rRNA gene sequence analysis, it is closely related to Microbacterium arborescens and Microbacterium imperiale; however, DNA-DNA hybridization showed reassociation values less than $70 \%$ with the type strains of these species. In chemotaxonomic analyses, the major menaquinones detected were $\mathrm{MK}-12, \mathrm{MK}-13$ and $\mathrm{MK}-11$ and the major fatty acids were anteiso- $C_{15: 0}$, anteiso- $C_{17: 0}$ and iso- $C_{16: 0}$; the peptidoglycan was of the type $\mathrm{B} 2 \beta$. The $\mathrm{G}+\mathrm{C}$ content determined was $69 \mathrm{~mol} \%$. Based on the present data, it is proposed that strain XIL02 ${ }^{\top}\left(=\right.$ LMG $20991^{\top}=$ CECT $\left.5976^{\top}\right)$ be classified as the type strain of a novel Microbacterium species, for which the name Microbacterium ulmi sp. nov. is proposed.
\end{abstract}

Xylan is a heterogeneous polymer composed of 1,4-linked $\mathrm{D}$-xylosyl residues that is present in plant cell walls. Microbial degradation of xylan requires the action of several enzymes such as $\beta$-1,4-xylanases, arabinofuranosidases, $\beta$-glucuronidases and $\beta$-xylosidases, which are produced by a wide range of micro-organisms, many of them belonging to the high-G $+\mathrm{C}$ Gram-positive bacteria (Beg et al., 2000; Busch \& Stutzenberger, 1997; Chamberlain \& Crawford, 2000; Rivas et al., 2003; Ruiz-Arribas et al., 1995; Mayorga-Reyes et al., 2002; Wang et al., 1998).

A study was undertaken to investigate the bacterial diversity in decayed trees of Ulmus nigra with the aim of isolating xylanolytic strains. A series of coryneform bacteria were isolated from various samples; one of these strains produced significant xylan hydrolysis activity and was chosen for further study. Chemotaxonomic, morphological, physiological and genetic characterization of this strain suggested that it belongs to the emended genus Microbacterium (Takeuchi \& Hatano, 1998), which accommodated 33 species with validly published names at the time of writing.

Published online ahead of print on 17 October 2003 as DOI 10.1099/ ijs.0.02724-0.

The GenBank/EMBL/DDBJ accession number for the $16 \mathrm{~S}$ rDNA sequence of isolate XILO2 ${ }^{\top}$ is AY062021.

A $16 S$ rDNA-based neighbour-joining tree including all species of Microbacterium is available as supplementary material in IJSEM Online.
Members of the genus Microbacterium contain the unusual type-B peptidoglycan, and strains representing these species have been isolated from various sources (Zlamala et al., 2002). The data presented in this paper indicate that this strain represents a novel species of the genus Microbacterium, for which the name Microbacterium ulmi sp. nov. is proposed.

A sample of sawdust from a decayed tree of $U$. nigra was collected under aseptic conditions and $1 \mathrm{~g}$ was suspended in $100 \mathrm{ml}$ sterile water and stirred for $30 \mathrm{~min}$. From this suspension, $100 \mu \mathrm{l}$ was spread on XED medium $(0.7 \%$ xylan, $0.3 \%$ yeast extract and $2.5 \%$ agar) and incubated at $28{ }^{\circ} \mathrm{C}$. A bacterial strain that produced a conspicuous clearing zone around the area of growth was isolated after 10 days incubation and a pure culture was maintained as a glycerol suspension $(25 \%, \mathrm{v} / \mathrm{v})$ at $-80{ }^{\circ} \mathrm{C}$.

Isolate XIL02 ${ }^{\mathrm{T}}$ was observed by phase-contrast microscopy using 48-h-old cultures grown on nutrient broth to check for cell shape and motility. Cells were also Gram-stained as described by Doetsch (1981).

DNA extraction, PCR amplification of the 16S rRNA gene and sequencing of the PCR products were performed as described previously (Rivas et al., 2003). An almost complete 16S rRNA gene sequence was obtained and compared with those from the public databases. Sequences were aligned using the CLUSTAL X software (Thompson et al., 
1997). An evolutionary-distance matrix was calculated using the algorithm of Jukes \& Cantor (1969). The phylogenetic tree was constructed using the neighbour-joining method (Saitou \& Nei, 1987) and its topology was compared to that of a tree obtained using the maximum-parsimony method (Fitch, 1971). Bootstrap analyses were based on 1000 resamplings. The MEGA2 package (Kumar et al., 2001) was used for all analyses.

Strain XIL02 ${ }^{\mathrm{T}}$ was cultivated in TSB (Becton Dickinson) for 4 days at $28^{\circ} \mathrm{C}$ in a rotary shaker (90 r.p.m.) for cell wall and menaquinone analyses. The same medium amended with $1.5 \%$ agar was used to cultivate the strain for fatty acid composition analysis. Menaquinone and cellular fatty acid compositions were determined as described by Zimmermann et al. (1998). Determination of the peptidoglycan type was carried out as described by Schleifer (1985) and Schleifer \& Kandler (1972). Sugar analyses were performed according to described procedures (Staneck \& Roberts, 1974).

The ability to solubilize phosphate was detected in YED-P plates (3 g yeast extract, $7 \mathrm{~g}$ glucose, $15 \mathrm{~g}$ agar and $3 \mathrm{~g}$ dibasic calcium phosphate $1^{-1}$ ) as described previously (Peix et al., 2001). Amylase, catalase and oxidase activities were detected as described by Rivas et al. (2003). Casein hydrolysis activity was detected on skimmed milk agar. Cellulases were detected after 7 days incubation on plates containing $0.5 \%$ carboxymethylcellulose as the carbon source, $0 \cdot 3 \%$ yeast extract and $1 \cdot 5 \%$ agar. Plates were stained with a $1 \%$ aqueous Congo red solution. Other physiological and biochemical tests were done using API $20 \mathrm{NE}$ and API 50CH strips (bioMérieux) following the manufacturer's instructions.

DNA for base composition analysis was prepared according to Chun \& Goodfellow (1995). The G +C content of DNA was determined using the thermal denaturation method (Mandel \& Marmur, 1968).

DNA-DNA relatedness was tested [in $2 \times$ SSC plus $10 \%$ $(\mathrm{v} / \mathrm{v})$ DMSO at $68^{\circ} \mathrm{C}$ ] between strain XIL02 ${ }^{\mathrm{T}}$ and strains Microbacterium arborescens DSM 20754 ${ }^{\mathrm{T}}$ and Microbacterium imperiale DSM $20530^{\mathrm{T}}$. DNA was isolated using the procedure of Cashion et al. (1977) and DNA-DNA hybridization was carried out as described by De Ley et al. (1970) with the modification of Huß et al. (1983) and Escara \& Hutton (1980). Renaturation rates were calculated using the TRANSFER.BAS program (Jahnke, 1992).

Isolate $\mathrm{XIL02^{ \textrm {T } }}$ was a Gram-positive, aerobic, non-motile, non-spore-forming and rod-shaped organism. Colonies on nutrient agar or XED medium showed a typical coryneform morphology. They were convex, smooth, white, opaque and 1-3 mm in diameter within 7 days at $28^{\circ} \mathrm{C}$.

An almost complete 16S rRNA gene sequence was obtained for isolate XIL02 ${ }^{\mathrm{T}}$ and this indicated that the organism was phylogenetically related to members of the genus

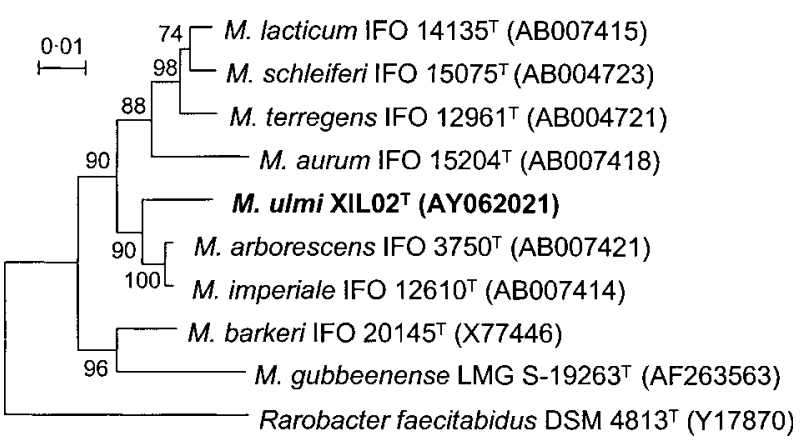

Fig. 1. Phylogenetic dendrogram based on comparison of the 16S rRNA gene sequence of Microbacterium ulmi sp. nov. $\mathrm{XILO}^{\top}$ within the genus Microbacterium. The significance of branches is indicated by bootstrap percentages based on 1000 resamplings. Bar, 1 substitution per 100 nt.

Microbacterium within the family Microbacteriaceae. Fig. 1 shows the relationship of strain $\mathrm{XILO2}^{\mathrm{T}}$ with its nearest phylogenetic relatives based on the neighbour-joining method. The closest relatives were $M$. imperiale $(97 \cdot 8 \%$ similarity) and $M$. arborescens $(97 \cdot 4 \%)$. Similar results were obtained using the maximum-parsimony method (data not shown). A fuller phylogenetic tree that includes all Microbacterium species with validly published names can be found as supplementary material in IJSEM Online.

Strain XIL02 ${ }^{\mathrm{T}}$ showed high xylanase and amylase activity; moderate cellulase production was also observed. Other phenotypic properties can be found in the species description and in Table 1.

The ability of isolate $\mathrm{XIL} 02^{\mathrm{T}}$ to solubilize phosphate in the form of dibasic calcium phosphate was detected after 7 days. Phosphate-solubilizing bacteria can play an important role in plant nutrition through an increase in phosphorus uptake by plants (Antoun et al., 1998; Chabot et al., 1998; Rodríguez \& Fraga, 1999), and their use as plantgrowth-promoting rhizobacteria may be an important contribution to biofertilization of agricultural crops. Most strains studied for this purpose belong to the $\alpha$-proteobacteria, especially members of the genera Mesorhizobium and Rhizobium (Peix et al., 2001). During a screening programme for phosphate-solubilizing strains, we isolated strain $\mathrm{XIL02}{ }^{\mathrm{T}}$; to our knowledge, this is the first report of a Microbacterium strain that solubilizes inorganic phosphate. It is worth mentioning that a laboratory bacterial contaminant characterized and identified as Friedmanniella spumicola (BUTO1) also produced significant phosphate-clearing zones when it was incubated on a medium that contained dibasic calcium phosphate as the only phosphorus source (M. E. Trujillo, unpublished data). These data suggest that the biodiversity of phosphatesolubilizing bacteria is still poorly understood and that isolation of these micro-organisms is not restricted to the soil. On the other hand, Gram-positive bacteria with high 
Table 1. Characteristics that differentiate Microbacterium ulmi sp. nov. XILO2 ${ }^{\top}$ from its nearest phylogenetic neighbours

+, Positive; -, negative; V, variable; ND, not determined; W, weak. Abbreviations: ai, anteiso-branched; i, iso-branched; Fuc, fucose; Gal, galactose; Man, mannose; Rha, rhamnose; 6dTal, 6-deoxytalose; Xyl, xylose; Lys, lysine; Orn, ornithine. Data from Behrendt et al. (2001), Matsuyama et al. (1999) and this study. Cells of all three species are short rods.

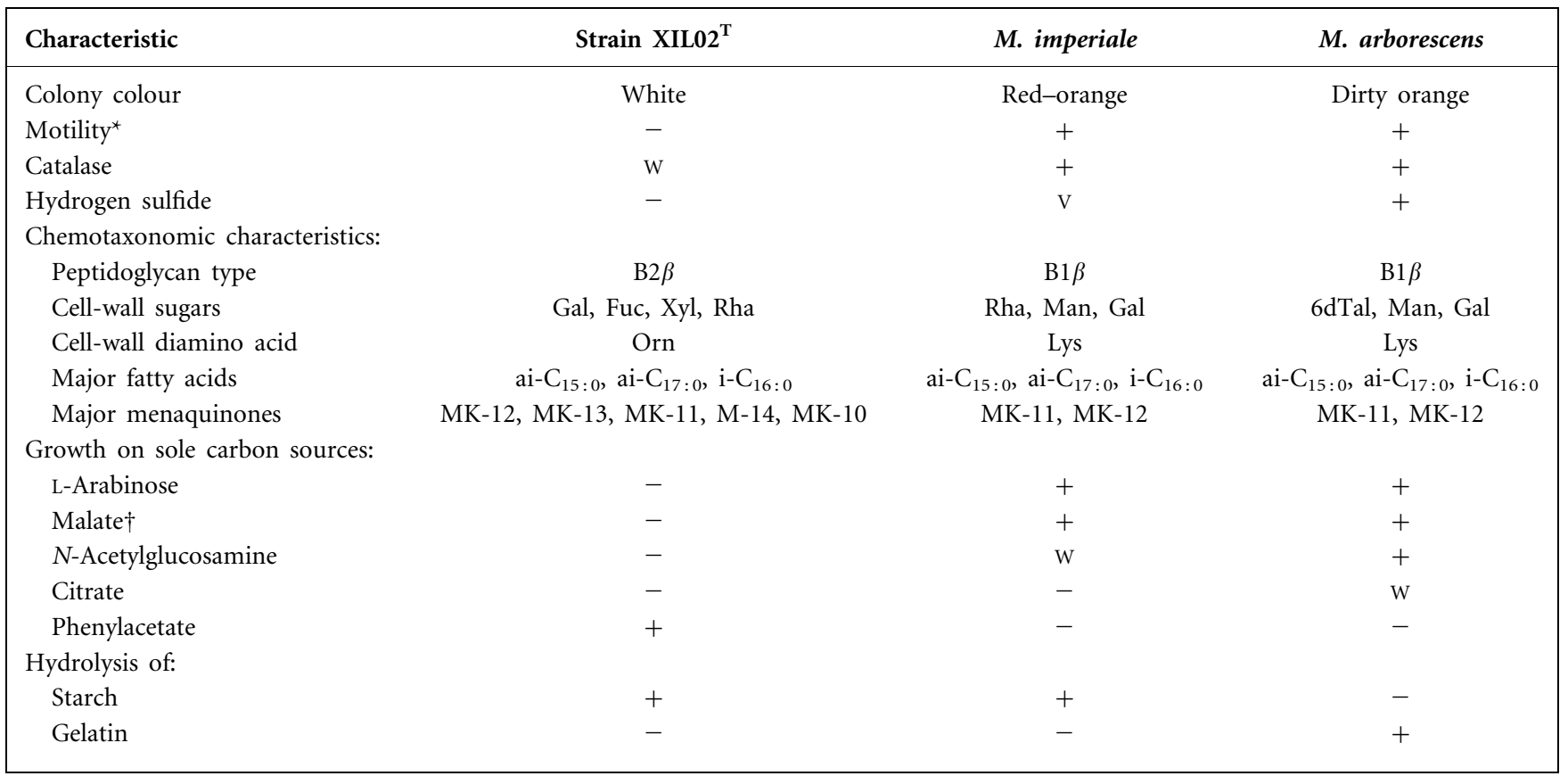

${ }^{\star} 67 \%$ of the Microbacterium species described are non-motile.

$\dagger 50 \%$ of Microbacterium strains positive, $33 \%$ negative, while the remaining $17 \%$ either present a weak reaction or different results have been reported.

$\mathrm{G}+\mathrm{C}$ content have been observed as dominant members of phosphate-removing activated-sludge communities (Bond et al., 1995; Maszenan et al., 1999) and are believed to play a major role in phosphorus turnover. It cannot be concluded whether phosphate removal is linked to the solubilization of rock phosphate; however, a better knowledge of these processes will improve our understanding of the diversity and interactions of these micro-organisms.

The presence of the D-diamino acid D-ornithine in the cell wall indicated that strain XIL02 ${ }^{\mathrm{T}}$ contained the unusual peptidoglycan type B2 (Schleifer \& Kandler, 1972), which has been reported for $67 \%$ of strains that currently belong to the genus Microbacterium (Behrendt et al., 2001). Other species, including M. arborescens and M. imperiale, contain L-lysine as the cell-wall diamino acid (Behrendt et al., 2001; Takeuchi \& Hatano, 1998). The cell-wall sugars detected for strain XIL02 ${ }^{\mathrm{T}}$ were galactose, fucose, xylose and rhamnose, while mannose was not found. Galactose and rhamnose have been found in cell walls of many other Microbacterium species, while fucose has only been reported for Microbacterium aurantiacum and Microbacterium aurum and xylose has been detected in Microbacterium chocolatum and Microbacterium laevaniformans. The cellular fatty acid pattern of strain XIL02 ${ }^{\mathrm{T}}$ was composed of iso- and anteisobranched fatty acids. The main fatty acids detected were anteiso- $\mathrm{C}_{15: 0}$, anteiso- $\mathrm{C}_{17: 0}$ and iso- $\mathrm{C}_{16: 0}$. These results are in accordance with those reported for the genus Microbacterium. The major isoprenoid quinones detected for this strain were MK-12 and MK-13, with minor amounts of MK-11 and MK-14 and traces of MK-10. This pattern has been reported for other Microbacterium species, including Microbacterium arabinogalactonolyticum, Microbacterium esteraromaticum, Microbacterium terregens, Microbacterium trichothecenolyticum and Microbacterium keratanolyticum (Behrendt et al., 2001). The major polar lipids detected for strain XIL02 ${ }^{\mathrm{T}}$ were phosphatidylglycerol, diphosphatidylglycerol (cardiolipin) and an unknown glycolipid. Chemotaxonomic differences found between strain XIL02 ${ }^{\mathrm{T}}$ and its closest phylogenetic relatives are shown in Table 1.

The $\mathrm{G}+\mathrm{C}$ content of strain XIL02 ${ }^{\mathrm{T}}$ was $69 \mathrm{~mol} \%$. This value is similar to those obtained in species from the genus Microbacterium.

DNA-DNA reassociation studies were used to confirm the species status of the novel isolate in relation to its closest phylogenetic neighbours. The results of DNA-DNA hybridization showed that strain $\mathrm{XIL}^{\mathrm{T}}{ }^{\mathrm{T}}$ presented 43.9 and $32.6 \%$ relatedness, respectively, with $M$. arborescens DSM $20754^{\mathrm{T}}$ and $M$. imperiale DSM $20530^{\mathrm{T}}$. These results indicate that isolate XIL02 ${ }^{\mathrm{T}}$ does not belong to either of these species 
when the recommendation of a threshold value of $70 \%$ DNA-DNA similarity for species definition is considered (Wayne et al., 1987).

Therefore, on the basis of phylogenetic, chemotaxonomic and phenotypic data, we propose that isolate XIL $02^{\mathrm{T}}$ should be classified as the type strain a novel species, for which the name Microbacterium ulmi sp. nov. is proposed.

\section{Description of Microbacterium ulmi sp. nov.}

Microbacterium ulmi (ul'mi. L. gen. fem. n. ulmi of the elm tree).

Gram-positive, aerobic or facultatively anaerobic, nonmotile, non-spore-forming rods. It grows between 15 and $37^{\circ} \mathrm{C}$. The $\mathrm{pH}$ range for growth is $5-8$. Catalase- and oxidase-negative. Utilizes D-arabinose, carboxymethylcellulose, cellobiose, D-fructose, gentiobiose, maltose, mannitol, D-mannose, phenylacetate, starch and xylan as carbon sources. Does not use L-arabinose, malate, $\mathrm{N}$-acetyl glucosamine or citrate as carbon sources. Aesculin, casein and gelatin are hydrolysed; does not reduce nitrate. Arginine dihydrolase, ornithine decarboxylase, lysine decarboxylase, tryptophan deaminase and urease are not produced. Chemotaxonomic properties are listed in Table 1.

The type strain is strain XIL02 ${ }^{\mathrm{T}}\left(=\mathrm{LMG} 20991^{\mathrm{T}}=\mathrm{CECT}\right.$ $\left.5976^{\mathrm{T}}\right)$, isolated from sawdust of a decayed tree of Ulmus nigra.

\section{Acknowledgements}

This work was supported by the Junta de Castilla y León (Spanish Government). The staff of the DSMZ are kindly acknowledged for their help with chemotaxonomic and DNA-DNA hybridization analyses.

\section{References}

Antoun, H., Beauchamp, C. J., Goussard, N., Chabot, R. \& Lalande, R. (1998). Potential of Rhizobium and Bradyrhizobium species as growth promoting rhizobacteria on non-legumes: effect on radishes (Raphanus sativus L.). Plant Soil 204, 57-67.

Beg, Q. K., Bhushan, B., Kapoor, M. \& Hoondal, G. S. (2000). Production and characterization of thermostable xylanase and pectinase from Streptomyces sp. QG-11-3. J Ind Microbiol Biotechnol 24, 396-402.

Behrendt, U., Ulrich, A. \& Schumann, P. (2001). Description of Microbacterium foliorum sp. nov. and Microbacterium phyllosphaerae sp. nov., isolated from the phyllosphere of grasses and the surface litter after mulching the sward, and reclassification of Aureobacterium resistens (Funke et al. 1998) as Microbacterium resistens comb. nov. Int J Syst Evol Microbiol 51, 1267-1276.

Bond, P. L., Hugenholtz, P., Keller, J. \& Blackall, L. L. (1995). Bacterial community structures of phosphate-removing and nonphosphate-removing activated sludges from sequencing batch reactors. Appl Environ Microbiol 61, 1910-1916.

Busch, J. E. \& Stutzenberger, F. J. (1997). Xylanase biosynthesis in Thermomonospora curvata is not repressed by glucose. Bioresour Technol 60, 81-85.
Cashion, P., Holder-Franklin, M. A., McCully, J. \& Franklin, M. (1977). A rapid method for the base ratio determination of bacterial DNA. Anal Biochem 81, 461-466.

Chabot, R., Beauchamp, C. J., Kloepper, J. W. \& Antoun, H. (1998). Effect of phosphorus on root colonization and growth promotion of maize by bioluminescent mutants of phosphate-solubilizing Rhizobium leguminosarum biovar phaseoli. Soil Biol Biochem 30, $1615-1618$.

Chamberlain, K. \& Crawford, D. L. (2000). Thatch biodegradation and antifungal activities of two lignocellulolytic Streptomyces strains in laboratory cultures and in golf green turfgrass. Can J Microbiol 46, $550-558$.

Chun, J. \& Goodfellow, M. (1995). A phylogenetic analysis of the genus Nocardia with $16 \mathrm{~S}$ rRNA gene sequences. Int J Syst Bacteriol 45, 240-245.

De Ley, J., Cattoir, H. \& Reynaerts, A. (1970). The quantitative measurement of DNA hybridization from renaturation rates. Eur $J$ Biochem 12, 133-142.

Doetsch, R. N. (1981). Determinative methods of light microscopy. In Manual of Methods for General Bacteriology, pp. 21-33. Edited by P. Gerhardt, R. G. E. Murray, R. N. Costilow, E. W. Nester, W. A. Wood, N. R. Krieg \& G. B. Phillips. Washington, DC: American Society for Microbiology.

Escara, J. F. \& Hutton, J. R. (1980). Thermal stability and renaturation of DNA dimethyl sulfoxide solutions: acceleration of the renaturation rate. Biopolymers 19, 1315-1327.

Fitch, W. M. (1971). Toward defining the course of evolution: minimal change for a specific tree topology. Syst Zool 20, 406-416.

Huß, V. A. R., Festl, H. \& Schleifer, K. H. (1983). Studies on the spectrometric determination of DNA hybridization from renaturation rates. Syst Appl Microbiol 4, 184-192.

Jahnke, K. D. (1992). Basic computer program for evaluation of spectroscopic DNA renaturation data from GILFORD System 2600 spectrometer or a PC/XT/AT type personal computer. J Microbiol Methods 15, 61-73.

Jukes, T. H. \& Cantor, C. R. (1969). Evolution of protein molecules. In Mammalian Protein Metabolism, vol. 3, pp. 21-132. Edited by H. N. Munro. New York: Academic Press.

Kumar, S., Tamura, K., Jakobsen, I. B. \& Nei, M. (2001). MEGA2: molecular evolutionary genetics analysis software. Bioinformatics 17, 1244-1245.

Mandel, M. \& Marmur, J. (1968). Use of ultraviolet absorbance temperature profile for determining the guanine plus cytosine content of DNA. Methods Enzymol 12B, 195-206.

Maszenan, A. M., Seviour, R. J., Patel, B. K. C., Schumann, P., Burghardt, J., Webb, R. I., Soddell, J. A. \& Rees, G. N. (1999). Friedmanniella spumicola sp. nov. and Friedmanniella capsulata sp. nov. from activated sludge foam: Gram-positive cocci that grow in aggregates of repeating groups of cocci. Int J Syst Bacteriol 49, 1667-1680.

Matsuyama, H., Kawasaki, K., Yumoto, I. \& Shida, O. (1999). Microbacterium kitamiense sp. nov., a new polysaccharide-producing bacterium isolated from the wastewater of a sugar-beet factory. Int J Syst Bacteriol 49, 1353-1357.

Mayorga-Reyes, L., Morales, Y., Salgado, L. M., Ortega, A. \& Ponce-Loyola, T. (2002). Cellulomonas flavigena: characterization of an endo-1,4-xylanase tightly induced by sugarcane bagasse. FEMS Microbiol Lett 214, 205-209.

Pearson, W. R. \& Lipman, D. J. (1988). Improved tools for biological sequence comparison. Proc Natl Acad Sci U S A 85, 2444-2448.

Peix, A., Rivas-Boyero, A. A., Mateos, P. F., Rodríguez-Barrueco, C., Martínez-Molina, E. \& Velázquez, E. (2001). Growth promotion of 
chickpea and barley by a phosphate solubilizing strain of Mesorhizobium mediterraneum under growth chamber conditions. Soil Biol Biochem 33, 103-110.

Reynolds, E. S. (1963). The use of lead citrate at high $\mathrm{pH}$ as an electron-opaque stain in electron microscopy. J Cell Biol 17, 208-212.

Rivas, R., Sánchez, M., Trujillo, M. E., Zurdo-Piñeiro, J. L., Mateos, P. F., Martínez-Molina, E. \& Velázquez, E. (2003). Xylanimonas cellulosilytica gen. nov., sp. nov., a xylanolytic bacterium isolated from a decayed tree (Ulmus nigra). Int J Syst Evol Microbiol 53, 99-103.

Rodríguez, H. \& Fraga, R. (1999). Phosphate solubilizing bacteria and their role in plant growth promotion. Biotechnol Adv 17, 319-339.

Ruiz-Arribas, A., Fernández-Abalos, J. M., Sánchez, P., Garda, A. L. \& Santamaría, R. I. (1995). Overproduction, purification, and biochemical characterization of a xylanase (Xys1) from Streptomyces halstedii JM8. Appl Environ Microbiol 61, 2414-2419.

Saitou, N. \& Nei, M. (1987). The neighbor-joining method: a new method for reconstructing phylogenetic trees. Mol Biol Evol 4, 406-425.

Schleifer, K. H. (1985). Analysis of the chemical composition and primary structure of murein. Methods Microbiol 18, 123-156.

Schleifer, K. H. \& Kandler, O. (1972). Peptidoglycan types of bacterial cell walls and their taxonomic implications. Bacteriol Rev 34, 407-477.
Staneck, J. L. \& Roberts, G. D. (1974). Simplified approach to identification of aerobic actinomycetes by thin-layer chromatography. Appl Microbiol 28, 226-231.

Takeuchi, M. \& Hatano, K. (1998). Union of the genera Microbacterium Orla-Jensen and Aureobacterium Collins et al. in a redefined genus Microbacterium. Int J Syst Bacteriol 48, 739-747.

Thompson, J. D., Gibson, T. J., Plewniak, F., Jeanmougin, F. \& Higgins, D. G. (1997). The CLUSTAL_X windows interface: flexible strategies for multiple sequence alignment aided by quality analysis tools. Nucleic Acids Res 25, 4876-4882.

Wang, F., Whitaker, R. D. \& Batt, C. A. (1998). Production of glucose isomerase in a recombinant strain of Streptomyces lividans. Appl Microbiol Technol 50, 65-70.

Wayne, L. G., Brenner, D. J., Colwell, R. R. \& 9 other authors (1987). International Committee on Systematic Bacteriology. Report of the ad hoc committee on reconciliation of approaches to bacterial systematics. Int J Syst Bacteriol 37, 463-464.

Zimmermann, O., Spröer, C., Kroppenstedt, R. M., Fuchs, E., Köchel, H. G. \& Funke, G. (1998). Corynebacterium thomssenii sp. nov., a Corynebacterium with $N$-acetyl- $\beta$-glucosaminidase activity from human clinical specimens. Int J Syst Bacteriol 48, 489-494.

Zlamala, C., Schumann, P., Kämpfer, P., Valens, M., RossellóMora, R., Lubitz, W. \& Busse, H.-J. (2002). Microbacterium aerolatum sp. nov., isolated from the air in the 'Virgilkapelle' in Vienna. Int J Syst Evol Microbiol 52, 1229-1234. 